Article

\title{
Assessing Young Consumers' Responses to Sustainable Labels: Insights from a Factorial Experiment in Italy
}

\author{
Carla Rossi * (iD and Francesca Rivetti * \\ Department of Mathematics, Computer Science and Economics, University of Basilicata, via dell'Ateneo Lucano 10, \\ 85100 Potenza, Italy \\ * Correspondence: carla.rossi@unibas.it (C.R.); francesca.rivetti@unibas.it (F.R.)
}

Received: 7 October 2020; Accepted: 27 November 2020; Published: 3 December 2020

check for updates

\begin{abstract}
This study provides insights into young consumers' responses to sustainable labels. Drawing on signaling theory, the article studies how third-party labels (TPLs) act and interact with company-level claims, trying to better understand their impact on young consumers' perceptions and willingness to buy (pay for) a chocolate bar. A between-subjects factorial experiment—conducted by manipulating third-party sustainable labels (presence/absence of the labels) and self-declared claims (absence of the claim, formal claim, and friendly claim) —was used to test: (a) the effect of TPLs and self-declared claims on consumers' perceptions, purchase intention, and willingness to pay, (b) whether this effect was mediated through the perceived credibility of the sustainability message, and (c) what kind of tone-of-voice adopted in the company's claim was more effective. Data were collected via an online survey among a sample of 315 consumers (age range: 18-39 years) in South Italy. We found that third-party labels, "alone" were not effective in influencing consumers' perceptions and willingness to buy/pay, while a self-declared claim, especially if characterized by a formal tone of voice, had a much more relevant impact. The combination of TPLs and self-declaration affected most consumers' willingness to pay when the copy claim was informal. The perceived credibility of the sustainability message mediated the relationships between self-declared claims and the majority of the dependent variables, while, with reference to the relationship between TPLs and dependent variables, it did not act as a mediator.
\end{abstract}

Keywords: labeling; sustainability; experimental design; young consumers; willingness to pay; chocolate bar

\section{Introduction}

Consumer demand for sustainable products is growing but their market share still remains small, compared to conventional alternatives [1-4]. Even though more and more consumers claim to be worried about the socio-environmental impact of the products they buy, they do not often display corresponding behaviors [5-8]. This discrepancy—commonly observed in the literature and labelled as "attitude-behavior gap" - is undeniably a big challenge for policymakers, companies, and non-profit organizations aiming to promote sustainable consumption [6,9-14].

Thus, although consumer demand for sustainable products is growing-for some categories even faster than the overall market [15] — there is still space to further encourage sustainable consumer behaviors. Labeling is one means that companies adopt to communicate their efforts towards sustainability and to promote responsible consumption [16-19].

According to ecolabelindex.com (the largest global directory of ecolabels), 457 labeling schemes are available in 199 countries, of which 148 include standards for food. The proliferation of 
environmental and ethical labels, while being a signal of a growing corporate commitment to sustainability, undeniably contributed to generate consumers' doubts and confusion [20], making it more difficult to distinguish which label is certified by a third party (external label), which label is an internal, self-declared claim, and when this latter corresponds (or not) to authentic corporate engagement [21-23]. Consumers might thus encounter growing difficulties in identifying truly responsible firms, whose messages they can consider as trustworthy, even because they are more and more aware of the greenwashing phenomenon [24-26].

Younger consumers-commonly called the generation Y (Millennials) and Generation $\mathrm{Z}$ (Post-Millennials) - maintain a very positive attitude in relation to sustainability in general [27] and are sometimes depicted in the literature as more inclined toward sustainable behaviors, compared to older generations $[28,29]$. However, they too show a discrepancy between how they think and what they do when it comes to a sustainable consumption [30,31].

The purpose of this paper is therefore to shed light on young consumers' understanding, perception, and attitude toward sustainable labeling, as well as possible effects on purchase and consumption behavior, in order to better highlight the role that sustainability information plays in a food context. We chose to focus on the food industry - where the development of a sustainable system is complex, requiring a multi-actor approach [32] — because in this context, promoting a sustainable consumption is particularly challenging, since the consumers' choices are first of all based on convenience, taste, and price.

In detail, we addressed the following aspects:

- Familiarity with and understanding of sustainability labels.

- If and how sustainability information on packaging influences consumers' perceptions and their willingness to buy/pay.

- What kind of claim (third party, self-declared, or both) influences the most consumers perceived credibility of the sustainability message and consumers trust in product quality.

- What kind of "tone of voice" (more formal and detached vs. more emotional and friendly) is more effective in influencing consumers perceptions and their willingness to pay.

First of all, the study investigates young consumers' level of familiarity and understanding of socio-environmental labels, which are increasingly appearing on food products, since businesses feel more urgent an imperative to prove their social and environmental credentials [33,34]. Sustainability labels can come in different forms. For example, according to the ISO, "Environmental labeling" can be issued in the form of: (1) "claims [ . . ] based on criteria set by a third party", such as governments or private non-commercial entities (Type 1), (2) "Self-declared environmental claims" (Type II), that refer to "claims based on self-declarations by manufacturers or retailers", (3) "Environmental declarations" (Type 3), or "eco-profiles", which refer to "claims [that] consist of quantified product information based on life cycle impacts" and are therefore mainly applicable to durable goods [35] (p. 1).

Literature argued that consumers could doubt the trustworthiness of self-declared claims [36,37], even because opportunistic behavior might be adopted by some companies, generating the well-known phenomenon of greenwashing [21,26].

Past research showed, indeed, that consumers generally consider independent certifications as more credible than self-declarations, due to the involvement of a third party from outside the company, who can provide a more objective assessment of a company's socio-environmental effort [34,38-42].

In these terms, independently assigned labels act as a "signal" capable of resolving any market failures, by eliminating information asymmetry about product quality $[43,44]$, providing a more objective assessment of a company's socio-environmental effort and hence improving consumers' trust in socio-environmental claims $[22,45,46]$.

However, in more recent years, a few studies have come to diverging conclusions on this issue. 
For example, Dekhili and Achabou [34] explored, through an empirical study involving 134 French consumers, the efficacy of firm-level responsible claims in the case of a well-known brand (Nespresso coffee) and came to the conclusion that self-declaration influenced consumer preference in virtually the same way as independent certification. They suggested carrying out comparative experiments with brands that had different levels of recognition.

Ertz et al. [47] conducted an experiment involving 321 Canadian consumers to examine the influence of different combinations of environmental product declarations on consumers' perceptions, in reference to a cereal bar with a fictitious brand. Their study revealed that environmental labeling alone did not significantly alter consumers' evaluations of product quality, credibility, and their willingness to pay; only the combined use of environmental labeling and elaborated (not succinct) self-declared environmental claims led to the highest perceptions of credibility and quality, but these better perceptions were not translated into a higher willingness to pay.

The aforementioned literature suggests that it is difficult to confirm the superiority of independent certification over self-declaration. It also outlines that the combined use of third-party and internal claims, though affecting consumer perceptions, do not always influence their willingness to pay. This latter consideration seems to contradict the results achieved in previous literature studies, which are equally focused on food products. In a lab experiment combined with product tasting, Tagbata and Sirieix [48] found that consumers are willing to pay 0.7 euro for a standard chocolate bar and an almost identical price for organic chocolate as for fair trade chocolate (1.25 and 1.31 euro). Rousseau [49] conducted a stated choice experiment (still associated with tasting) concerning the purchase of chocolate in Flanders (Belgium) to investigate the influence of labels-and their implied information-on consumption behavior. With respect to willingness to pay, she came to the conclusion that the premium price that respondents were willing to pay for a chocolate tablet with a fair-trade label was approximately $€ 2$ on average, while the premium price for a chocolate tablet with an organic label was surprisingly slightly negative (-€0.37).

Past research further suggests that the way the sustainability arguments are presented can make a difference. For example, Atkinson and Rosenthal [50] examined how some variables, including "argument specificity" could influence consumer trust and attitudes. Considering "specific arguments" like those that contain sufficient detail to substantiate claims in concrete terms, the authors concluded that more detailed, substantial claims might lead to higher levels of reported consumer trust and more favorable attitudes toward the product and label source.

Benoit-Moreau, Parguel, and Larceneaux [25] investigated the influence of three creative elements of a green advertisement (the usage of the color "green", the use of the word "sustainably", and the presence of a self-claimed ecological label) and they observed, among other things, that the internal eco-label had a greater impact on the perceived sincerity of the advertisement and on the attitude toward the advertiser, when it was associated with the semantic element "sustainably".

In other words, previous studies suggest that advertising execution elements can influence consumers' perceptions and their attitude toward the product/label. On these bases, the present research also tried to analyze the impact of a specific element of execution style-the tone of voice adopted in the self-declared claim copies. As known, the term "Tone of Voice" (ToV) is used to refer to the language styles/registers that a company uses to express a distinctive personality or set of values that differentiate its brands from those of competitors. The way brands communicate with consumers can be decisive in shaping consumer attitudes-it influences the level of consumer engagement, acting as a clue that addresses emotions rather than reason [51]. The marketing literature noticed the rise of a more emotional approach in companies' commercial communication, instead of a mere rational one (see, for example, [52]), the former having a more significant effect particularly on hedonic products [53]. One could, therefore, wonder what are the effects produced by the structure of the copy and its language style (more warm, emotional, and friendly, versus more rational and formal). The hypothesis, to be verified, is that more emotional (friendly) self-declared claims displayed on 
the product packages could have a greater influence, through psychological urges and consumer engagement, than formal claims.

Based on the aforementioned literature, the following hypotheses were formulated and tested in the study:

Hypothesis 1 (H1). There is a direct and significant relationship between third-party sustainability labels and consumer response (consumers' perceptions - of product quality and company's reliability — purchase intention, and willingness to pay).

Hypothesis 2 (H2). There is a direct and significant relationship between producers' self-declared sustainability claims and consumer response.

Hypothesis $\mathbf{2 b} \mathbf{( H 2 b ) . ~ A ~ s e l f - d e c l a r e d ~ c l a i m ~ c o n v e y e d ~ t h r o u g h ~ a ~ m o r e ~ f r i e n d l y ~ c o p y ~ i n f l u e n c e s ~ c o n s u m e r ~}$ response more than one conveyed through a formal copy.

Hypothesis 3 (H3). The consumer's willingness to pay increases the most when both elements (third-party label and self-declared claim) are present on the product package.

Hypothesis 4 (H4). The effects of external labeling and internal claims on consumer (cognitive and conative) response are mediated by the perceived credibility of the sustainability message.

\section{Methodology}

\subsection{Sampling and Data Collection Procedure}

We recruited a non-probabilistic, convenience sample of 315 millennials (young adults born between 1981 and 1996) and post-millennials (born between 1997 and 2012) living in South Italy. The final sample was made up of 200 women and 115 men. With regards to the age generation, there was an almost equal distribution of participants (165 millennials, 150 post-millennials), with an age range between 19 and 39 years.

Participants for this study-university students, enrolled in Economics and Management Courses, undergraduates and graduates-were invited by email to respond to a structured questionnaire (see Table A1 in Appendix A) and received general instructions. To reduce hypothesis guessing, participants were informed that the purpose of the study was to get an understanding of young people's attitudes/beliefs toward food product packaging. Interviewees were randomly assigned to one of the six experimental conditions (explained in the next subsection) and were invited to answer an online questionnaire consisting of four sections:

1. An introduction, aimed at detecting chocolate consumption habits and the factors considered before assuming a purchase decision.

2. An experiment, aimed at verifying the hypotheses outlined in the previous paragraph.

3. A section built to detect the participants' previous knowledge of socio-environmental labels. Respondents were asked to freely describe a socio-environmental label they had in their mind, in order to understand their level of spontaneous recall. Then, the level of familiarity and understanding with the certification schemes most adopted for cocoa was analyzed, studying whether respondents had ever seen four commonly used TPLs, and were able to recognize their goals by correctly associating each of them with the right meaning (suggested through a list of five possible options, of which one was incorrect, while the other were the purposes of the four certification schemes considered). The four TPLs considered were the ones which, according to KPMG, are the major certification schemes operating in the cocoa sector [54] (p. 98)-the EU organic label, the Fair Trade label, the Rainforest Alliance label, the UTZ Certified label. 
4. A series of questions dedicated to the demographic traits of the participants.

Anonymity was guaranteed to participants to minimize the social desirability bias, which can affect questionnaires in research about sustainable food [55]. A pre-test of the first version of the questionnaire was conducted on 20 University students to detect any problem or structural weakness. This step was useful to reformulate two questions that appeared ambiguous to interpret.

\subsection{Experimental Design and Measurement Instrument}

To test the hypotheses, we conducted a between-subject factorial experiment, following a $2 \times 3$ randomized design, in which we manipulated third-party sustainable labels (presence/absence of the labels) and self-declared claims (absence of the claim, formal claim, and friendly claim) (Table 1). The identification of "formal" and "friendly" modes refers to the "tone of voice" characterizing the claim, following what was specified in the previous paragraph. The self-declared claim was formulated following the suggestions provided by the International Organization for Standardization (ISO), with the aim of avoiding to appear too vague [56]. Inevitably, the formal claim sounded more factual, providing a more explicit "reason to believe" (the percentage of recycled paper used in the package), which was not provided in the "emotional version" of the claim (which equally stated that the paper used to wrap the product was totally recycled).

Table 1. The factorial design.

\begin{tabular}{llcccc}
\hline & & & INTERNAL CLAIM \\
\hline & & Absence of the Claim & Formal Claim & Friendly Claim \\
\hline \multirow{2}{*}{ THIRD-PARTY LABELS } & Absence of the labels & $\begin{array}{c}54 \text { subjects } \\
\text { (Condition 1) }\end{array}$ & $\begin{array}{c}52 \text { subjects } \\
\text { (Condition 2) }\end{array}$ & $\begin{array}{c}49 \text { subjects } \\
(\text { Condition 3) }\end{array}$ \\
\cline { 2 - 6 } & Presence of the labels & $\begin{array}{c}55 \text { subjects } \\
\text { (Condition 4) }\end{array}$ & $\begin{array}{c}53 \text { subjects } \\
\text { (Condition 5) }\end{array}$ & $\begin{array}{c}52 \text { subjects } \\
\text { (Condition 6) }\end{array}$ \\
\hline
\end{tabular}

The experimental stimuli consisted of a high-resolution picture of a chocolate bar package with a fictitious brand (Chocol.it). In each condition, the image was characterized by a different combination of third-party labels (absent, present), and self-declared claims (absence of the claim, formal claim, and friendly claim). These product representations were deliberately not referred to a specific flavor; in presenting the product, we asked the participants to imagine that this chocolate bar was of their favorite flavor.

A fictitious brand was considered as preferable to avoid that prior familiarity with existing brand and brand attachment or preferences could affect participants' responses. With regards the labels represented on the product packaging, our choice fell on Fairtrade and UTZ logos, which, according to the KPMG study [54], were the first two with reference to the volume of certified cocoa (Table 2).

Table 2. Volume Certified Cocoa (tonnes).

\begin{tabular}{cccc}
\hline & $\mathbf{2 0 1 0}$ & 2010 Share of Certified Cocoa & $\mathbf{2 0 1 1}$ \\
\hline Fair Trade & 106,400 & $39 \%$ & 150,000 \\
\hline UTZ & 70,000 & $25 \%$ & 214,000 \\
\hline RainForest & 56,000 & $20 \%$ & 98,400 \\
\hline Organic Europe & 42,500 & $15 \%$ & Not available \\
\hline & & Source: [54] (p. 98).
\end{tabular}

After exposing the participants to the stimuli (Figure 1), we asked them some questions concerning their perceptions/intentions about:

- Company's reliability and attention to consumers. 
- Purchase intention.

- The use of sustainable materials for production.

- Customers' trust in product quality.

- Positive word of mouth.

- Credibility of the company's environmental commitment.

- Third-party certification of information about the company's environmental efforts.

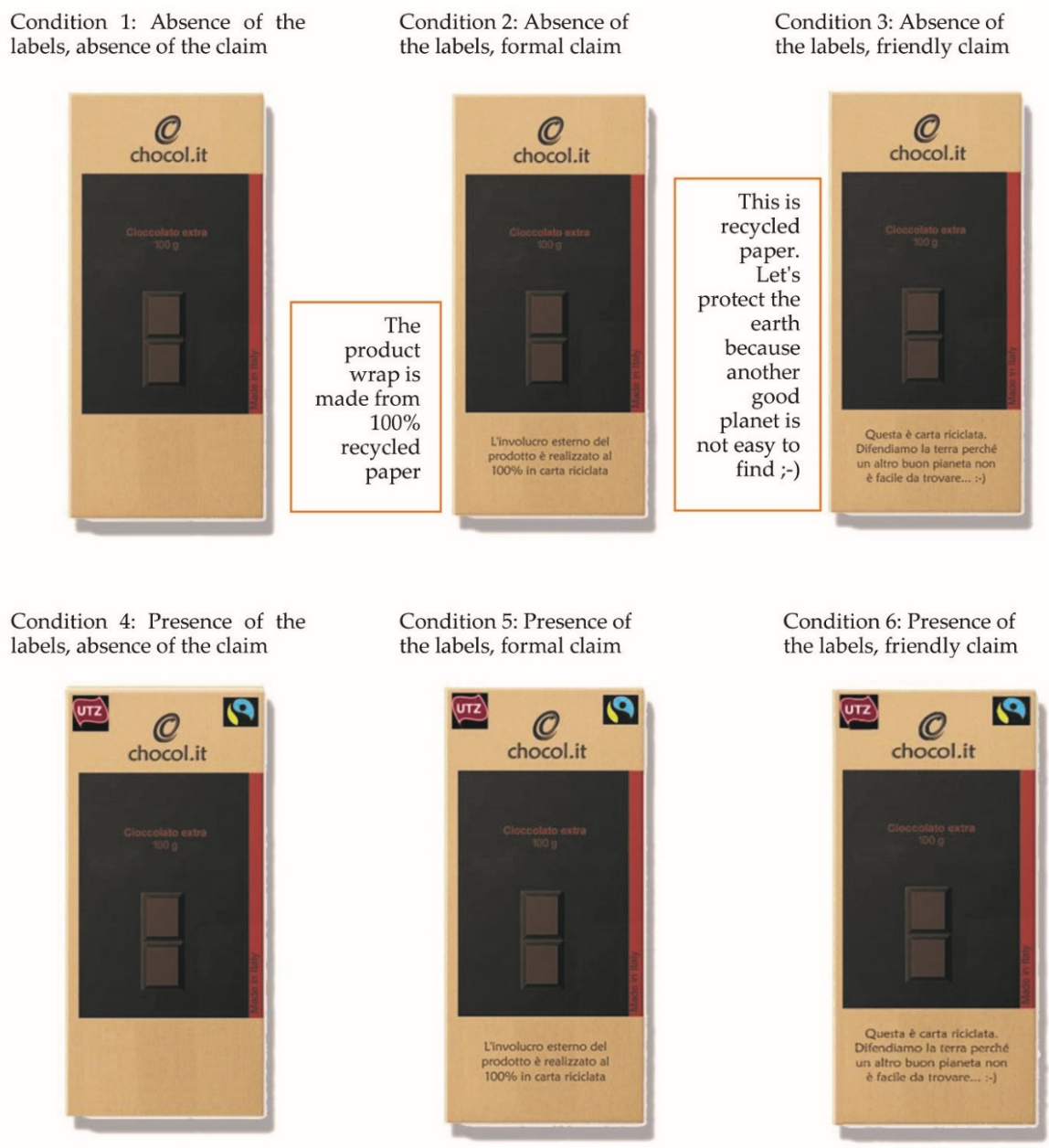

Figure 1. Visual Product Stimuli.

To measure these variables, we used a 5 -point Likert scale ( $1=$ "totally disagree"; $5=$ "totally agree" $)$. Following a consolidated approach in experimental studies in marketing e.g., [46,57], we built some constructs using the means of groups of items, as specified below, and we evaluated their reliability considering the value of Cronbach's alpha.

A first construct measured the perceived credibility of the sustainability message of the company. To build it, we used some items adapted from Ertz et al. [47] (p. 169), who in turn adapted them from Mohr et al. [58]: (1) "The environmental commitment announced on the package appears to be trustworthy in my eyes"; (2) "The company is believable when it communicates its efforts to reduce its impact on the environment"; (3) "The environmental information included in the packaging seems truthful to me". To measure the construct, we added a fourth item, adapted from Bradu et al. [57], to those already mentioned: (4) "To produce this chocolate bar the company used sustainably produced materials". The perceived credibility construct was found to be reliable, with a satisfactory Cronbach's alpha of 0.912 . 
Following Gosselt et al. [46] (p. 419), we used the following items, originally adopted by Becker-Olsen et al. [59], to measure the corporate reliability: (1) "[Organization] is a firm I can trust"; (2) "The [Organization] is a firm that cares about its customers" (Cronbach's alpha $=0.883$ ).

The consumer's trust in product quality was measured considering two of the three items that Ertz et al. [47] (p. 169) used to measure perceived product quality, referring to what Azhar and Elliott [60] previously highlighted: (1) "This product provides me with an impression of being of good quality"; (2) "I trust the quality of this product" (Cronbach's alpha $=0.916)$.

The behavioral intentions were measured with two items adapted from Gosselt et al. [46] (pp. 419-420) and proposed by Dodds [61]: (1) "If I had to buy a chocolate bar, there is a strong likelihood that I would buy the product here represented"; (2) "I would recommend this product to my friends" (Cronbach's alpha $=0.811$ ).

We also asked participants to express their willingness to pay to purchase the product. To assess the willingness to pay, we used Cameron and James' [62] "maximum price analysis". We informed respondents that the average market price for a chocolate bar was $€ 1.1$ and asked them the maximum amount of money they would be willing to pay for this bar.

Finally, participants were asked a question to check manipulation, concerning third-party certification of the information about the company's socio-environmental efforts.

\subsection{Mediation Analysis}

As specified in paragraph 1 , we hypothesized that the relationship between the independent variables (third-party labels and self-declared claim) and the dependent variables (consumer perceptions, intentions, and willingness to pay) was mediated by the perceived credibility of the sustainability message of the company. To verify if and in which cases perceived credibility acts as a mediator, we followed the approach proposed by Baron and Kenny [63] and then uploaded by Kenny et al., consisting of four steps [64] (pp. 259-260): (1) verification of the existence of "an effect that may be mediated", that is, $X$ significantly influenced $Y$, estimating and testing the regression coefficient; (2) in the same way, verification of the existence of a significant relationship between the $X$ and the hypothetical mediator (M); (3) verification of the existence of a significant relation between $X$, controlled for the hypothetical mediator $(M)$, and $Y$; and (4) comparison between the significance of the $\mathrm{X}-\mathrm{Y}$ relationship without considering $\mathrm{M}$ and the $\mathrm{X}-\mathrm{Y}$ relationship "controlling for $\mathrm{M}^{\text {"; }}$; in the second case, the regression coefficient should be not significantly different from 0 . If the fourth step is not met, while the first three steps are met, there is a "partial" mediation; instead, if all steps are met, the mediation is "complete" [64] (p. 260). Although this approach presents some criticalities and over time scholars developed further procedures to analyze mediation (e.g., $[65,66])$, it undoubtedly remains the most used and cited one.

\section{Results}

\subsection{Manipulation Check}

To assess the effectiveness of the manipulation, ensuring that respondents could properly perceive as expected the different conditions they were exposed to, all participants, regardless of experimental condition, indicated to what extent they agreed (using 5-point Likert scales) with the following statement: "Information on the company's socio-environmental efforts is certified by third parties". The results (Table 3) indicate that the external label indeed triggered the belief that third parties had certified the socio-environmental effort made by the company $(\mathrm{B}=0.679 ; p<0.001)$, whereas the internal claims, both formal $(\mathrm{B}=0.101 ; p=0.555)$ and friendly $(\mathrm{B}=-0.075 ; p=0.663)$, did not inspire the same belief. 
Table 3. The manipulation check.

\begin{tabular}{cccccc}
\hline Independent Variables & $\boldsymbol{B}$ & Std. Err. & $\mathbf{t}$ & Sig. & Adj. $\mathbf{R}^{\mathbf{2}}$ \\
\hline (Constant) & 2.300 & 0.139 & 16.591 & $<0.001$ & 0.064 \\
\hline Formal claim & 0.101 & 0.170 & 0.591 & 0.555 & \\
\hline Friendly claim & -0.075 & 0.172 & -0.436 & 0.663 & \\
\hline Pres. of the labels & 0.679 & 0.140 & 4.841 & $<0.001$ & \\
\hline
\end{tabular}

\subsection{Elements Considered in the Purchasing Choice and the Familiarity with the Sustainability Labels}

To gain a better understanding of respondents' purchasing behavior, we asked them to rate the importance ( $1=$ not at all important; $5=$ extremely important) of the different aspects that influence their choice when buying chocolate (Figure 2). Clearly, since chocolate consumption is a sensory experience, lived to satisfy a desire, the taste is the most important factor, considered of medium or high importance in $99 \%$ of the responses. Next, are the price $(95 \%)$, the expiration date $(90 \%)$, and the brand $(76 \%)$. Aspects such as the environmental and socio-ethical commitment of the producer (respectively, $73 \%$ and $71 \%$ ) are positioned in middle-table and are considered more, before assuming the purchase choice, than factors such as nutritional information $(69 \%)$, country of production $(66 \%)$, origin, and nature of raw materials (respectively, $64 \%$ and $60 \%$ ).

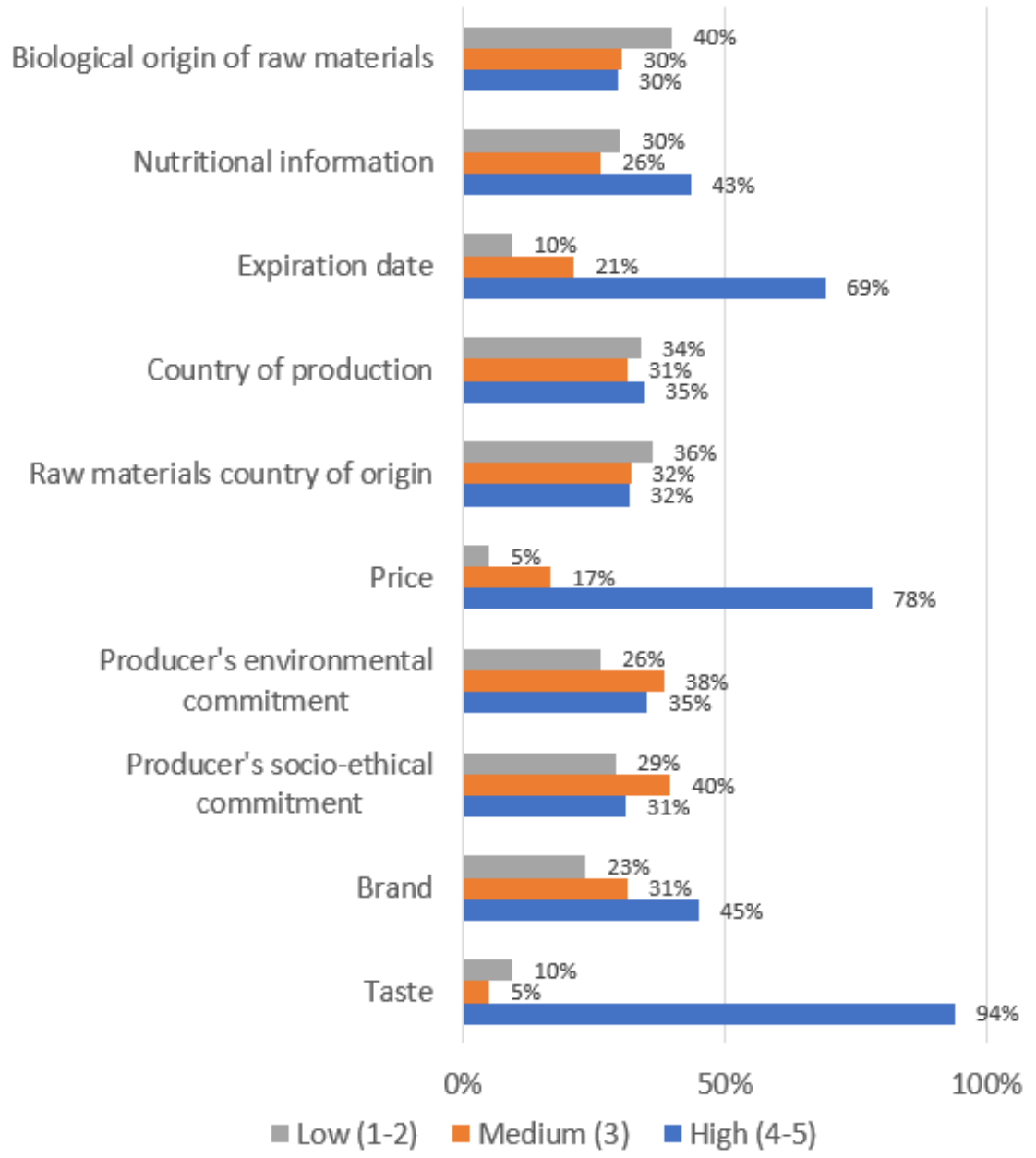

Figure 2. Aspects considered when buying chocolate.

We then checked the familiarity and understanding of the two sustainability labels used in the study, in addition to the other two that are commonly used for cocoa-Fair Trade, UTZ, Rainforest, and the 
EU Bio Logo. The results indicate that the majority (57.46\%) of study participants knew at least one of these logos (Table 4), but when we came to the analysis of data related to the knowledge ("What do you think this label means?"), we could verify that the overall understanding of the labels' purposes varied from moderate to poor (Table 5), and was deceiving with respect to the two TPLs used in this study (Fair Trade and UTZ).

Table 4. Declared number of familiar labels.

\begin{tabular}{ccc}
\hline Number of Labels & $\mathbf{n}$ & $\%$ \\
\hline 0 & 134 & $42.54 \%$ \\
\hline 1 & 68 & $21.59 \%$ \\
\hline 2 & 72 & $22.86 \%$ \\
\hline 3 & 31 & $9.84 \%$ \\
\hline 4 & 10 & $3.17 \%$ \\
\hline Total & 315 & $100.00 \%$ \\
\hline
\end{tabular}

Table 5. Recognition of the purpose of the labels.

\begin{tabular}{ccccc}
\hline & Fair Trade & UTZ & Rainforest & EU Bio Logo \\
\hline Not recognized & $84.44 \%$ & $77.46 \%$ & $31.75 \%$ & $49.52 \%$ \\
\hline Recognized & $15.56 \%$ & $22.54 \%$ & $68.25 \%$ & $50.48 \%$ \\
\hline
\end{tabular}

\subsection{The Relationships between Labeling and the Dependent Variables}

We hypothesized the presence of a direct and significant relationship between third-party sustainability labels and consumers' intentions/perceptions (H1), as well as between producers' self-declared sustainability claims and consumers' intentions/perceptions (H2).

Table 6 shows the results of the multiple regression, by which we tested these hypotheses.

Table 6. The impact of third-party labels and self-declared claims on customer perceptions, intentions, and willingness to pay.

\begin{tabular}{ccccccc}
\hline Dependent Variables & Independent Variables & $\boldsymbol{B}$ & Std. Err. & $\mathbf{t}$ & Sig. & ${\text { Adj. } \mathbf{R}^{\mathbf{2}}}^{\text {Corporate reliability }}$ \\
& (Constant) & 2.859 & 0.105 & 27.276 & $<0.001$ & 0.105 \\
\hline & Formal claim & 0.760 & 0.129 & 5.907 & $<0.001$ & \\
\hline & Friendly claim & 0.529 & 0.130 & 4.070 & $<0.001$ & \\
\hline & Pres. of the label & 0.180 & 0.106 & 1.701 & 0.090 & \\
\hline Trust in product quality & (Constant) & 3.003 & 0.113 & 26.488 & $<0.001$ & 0.045 \\
\hline & Formal claim & 0.540 & 0.139 & 3.878 & $<0.001$ & \\
\hline & Friendly claim & 0.448 & 0.141 & 3.187 & 0.002 & \\
\hline & Pres. of the label & 0.076 & 0.115 & 0.659 & 0.510 & \\
\hline Behavioral intentions & (Constant) & 2.707 & 0.107 & 25.223 & $<0.001$ & 0.056 \\
\hline & Formal claim & 0.595 & 0.132 & 4.516 & $<0.001$ & \\
\hline & Friendly claim & 0.409 & 0.133 & 3.077 & 0.002 & \\
\hline Willingness to pay & Pres. of the label & 0.063 & 0.109 & 0.584 & 0.560 & \\
\hline & (Constant) & 1.334 & 0.066 & 20.122 & $<0.001$ & 0.023 \\
\hline & Formal claim & 0.166 & 0.081 & 2.046 & 0.042 & \\
\hline & Friendly claim & 0.258 & 0.082 & 3.147 & 0.002 & \\
\hline & Pres. of the label & -0.008 & 0.067 & -0.114 & 0.910 & \\
\hline
\end{tabular}


The relationship between self-declared claims (both formal and friendly) and corporate reliability is statistically significant $(p<0.05)$. Moreover, we notice that the regression coefficient value is higher in the case of a formal label with respect to a friendly one. Instead, the relationship between the presence of the third-party labels and corporate reliability is on the verge of significance $(p=0.090)$.

With reference to trust in product quality, there is a significant relationship with formal and friendly claims, and the significance is higher in the case of a more formal tone. There is no significant relationship between third-party labels and trust $(p=0.51)$.

Moving on to behavioral intentions, we can observe a significant relationship with the formal claim $(p<0.001)$ and with the friendly claim $(p=0.002)$; here too there is no significant relationship with third-party labels $(p=0.56)$.

Finally, when coming to the analysis of the relationship between the independent variables and the willingness to pay, we can notice that a significant relationship exists between the two types of claims and the dependent variable. Contrary to what happens in the previous cases, the relationship between the friendly claim and the willingness to pay (WTP) $(p=0.002)$, however, is more significant than the relationship between the formal claim and WTP $(p=0.042)$. Compared to the intercept, the price increases when the claim is present on the package (and it is higher in the case of a friendly claim). Here too, the third-party labels do not significantly influence the dependent variable.

These results do not support Hypothesis 1 while confirming Hypothesis 2. H2b is not supported in all cases, except for the relationships between independent variables and willingness to pay. Contrary to what was assumed in Hypothesis $2 b$, focusing on the tone of voice of the self-declared claims, for all regressions performed, except in the last case (where the dependent variable was the willingness to pay), the coefficient estimate is higher when the tone of the claim is formal.

We then performed a multiple regression considering the willingness to pay as our dependent variable and the different conditions submitted to the attention of the participants as independent variables. In fact, the multiple regression presented before, set up to "extrapolate" the effects of the "formal claim", "informal claim", and "label" variables, did not allow us to examine the relationships of the six combinations with the WTP. As specified in Section 2.2, to assess the willingness to pay, we used the "maximum price analysis" [62]—-we asked the respondents to express the maximum amount of money they would be willing to pay to purchase the bar represented in the visual stimuli, after informing them about the average market price for a chocolate bar $(€ 1.1)$. Once verified that in our case the maximum average price $(€ 1.69)$ was expressed by participants who fell under condition 6 (chocolate packaging displaying third-party labels and an informal claim), we considered this group as the base-case of reference and tested the presence of significant relationships between each condition and the WTP. As shown in Table 7, there exist significant relationships between condition 4 (presence of the labels, absence of the claim) and the WTP $(p<0.001)$, as well as condition 1 (absence of the labels, absence of the claim) and the WTP $(p=0.019)$.

Table 7. The combinations of labeling and the willingness to pay.

\begin{tabular}{ccccccc}
\hline Dependent Variable & $\begin{array}{c}\text { Modalities of the } \\
\text { Independent Variable }\end{array}$ & $\boldsymbol{B}$ & Std. Err. & $\mathbf{t}$ & Sig. & Adj. $\mathbf{R}^{\mathbf{2}}$ \\
\hline Willingness to pay & (Constant) & 1.688 & 0.081 & 20.764 & $<0.001$ & 0.035 \\
\hline & Condition 5 & -0.213 & 0.115 & -1.856 & 0.064 & \\
\hline Condition 4 & -0.446 & 0.114 & -3.913 & $<0.001$ & \\
\hline Condition 3 & -0.209 & 0.117 & -1.783 & 0.076 \\
\hline Condition 2 & -0.171 & 0.115 & -1.488 & 0.138 \\
\hline Condition 1 & -0.270 & 0.114 & -2.355 & 0.019 \\
\hline
\end{tabular}

In these cases, the price decrease (with respect to condition 6, considered as the base-case), is particularly high: $-€ 0.45$ for condition 4 (the highest variation), when only the third-party labels appeared on the product package, and $-€ 0.27$ for condition 1 . When the product packaging displayed 
only the TPLs, without a self-declared claim (condition 4), the consumer declared his willingness to pay a maximum price of $€ 1.24$, showing the lowest WTP, even lower than in condition 1 , when the product packaging was plainer and displayed no symbols at all (neither the third-party nor the firm-level ones). Although it could appear surprising that participants did not express the lowest willingness to pay for condition 1, it could be assumed that graphic cleanliness of the package was perceived as an element of greater value than the mere presence of the third-party labels, whose purposes most of the participants ignored, as noted above (see Section 3.2). With regard to conditions 3 (absence of the third-party labels, friendly claim) and 5 (presence of the labels, formal claim), the variation in WTP is on the verge of significance and in both cases, it is about $-€ 0.21$. Instead, the relationship between condition 2 (absence of the label, formal claim) and the WTP is not significant $(p=0.138)$. These results almost completely confirm H3. The highest value of the WTP was expressed when the TPLs were combined with an informal claim; the combination between TPLs and formal claim revealed a lower WTP (with respect to the base-case), which was almost the same as the one expressed with reference to condition 3 (when only the friendly claim was displayed on the product packaging, without any external label).

\subsection{The Mediating Role of the Perceived Credibility of the Sustainability Message}

Following the approach described in paragraph $2.4[63,64]$, we verified whether the credibility of the sustainability message acted as a mediator in the context of the relationships between independent variables and consumer intentions, perceptions, and willingness to pay $(\mathrm{H} 4)$. In the previous paragraph, we already described step 1 , concerning the verification of the existence of significant relationships between third-party labels and the self-declared claims and the dependent variables.

Looking at Table 8, we can first examine the relationship between credibility, that is our hypothetical mediator (M), and the independent variables. All relationships are significant $(p<0.05)$. The formal claim has a stronger effect on credibility, since, compared to what happens for the other independent variables, it shows the highest regression coefficient (B). Moving on to the analysis of the relationships between credibility and the dependent variables, we observe that in all cases, they are significant $(p<0.001)$.

Table 8. The mediation effect of the credibility of the sustainability message.

\begin{tabular}{|c|c|c|c|c|c|c|}
\hline Dependent Variables & Independent Variables & $B$ & Std. Err. & $\mathbf{t}$ & Sig. & Adj. $\mathbf{R}^{2}$ \\
\hline \multirow[t]{4}{*}{ Credibility of the sust. ${ }^{*}$ message } & (Constant) & 2.841 & 0.106 & 26.780 & $<0.001$ & 0.117 \\
\hline & Formal claim & 0.781 & 0.130 & 5.996 & $<0.001$ & \\
\hline & Friendly claim & 0.472 & 0.132 & 3.587 & $<0.001$ & \\
\hline & Pres. of the label & 0.307 & 0.107 & 2.860 & 0.005 & \\
\hline \multirow[t]{5}{*}{ Corporate reliability } & (Constant) & 0.821 & 0.131 & 6.257 & $<0.001$ & 0.575 \\
\hline & Formal claim & 0.200 & 0.094 & 2.137 & 0.033 & \\
\hline & Friendly claim & 0.190 & 0.091 & 2.085 & 0.038 & \\
\hline & Pres. of the label & -0.040 & 0.074 & -0.537 & 0.592 & \\
\hline & Credibility of the sust. message & 0.717 & 0.039 & 18.581 & $<0.001$ & \\
\hline \multirow[t]{5}{*}{ Trust in product quality } & (Constant) & 0.737 & 0.137 & 5.364 & $<0.001$ & 0.575 \\
\hline & Formal claim & -0.083 & 0.098 & -0.848 & 0.397 & \\
\hline & Friendly claim & 0.072 & 0.096 & 0.750 & 0.454 & \\
\hline & Pres. of the label & -0.169 & 0.077 & -2.184 & 0.030 & \\
\hline & Credibility of the sust. message & 0.798 & 0.040 & 19.742 & $<0.001$ & \\
\hline
\end{tabular}


Table 8. Cont.

\begin{tabular}{|c|c|c|c|c|c|c|}
\hline Dependent Variables & Independent Variables & $B$ & Std. Err. & $\mathbf{t}$ & Sig. & Adj. $R^{2}$ \\
\hline \multirow[t]{5}{*}{ Behavioral intentions } & (Constant) & 0.591 & 0.132 & 4.470 & $<0.001$ & 0.566 \\
\hline & Formal claim & 0.013 & 0.094 & 0.142 & 0.887 & \\
\hline & Friendly claim & 0.058 & 0.092 & 0.631 & 0.529 & \\
\hline & Pres. of the label & -0.165 & 0.075 & -2.215 & 0.028 & \\
\hline & Credibility of the sust. message & 0.745 & 0.039 & 19.149 & $<0.001$ & \\
\hline \multirow[t]{5}{*}{ Willingness to pay } & (Constant) & 0.638 & 0.110 & 5.795 & $<0.001$ & 0.175 \\
\hline & Formal claim & -0.026 & 0.079 & -0.333 & 0.740 & \\
\hline & Friendly claim & 0.139 & 0.077 & 1.809 & 0.071 & \\
\hline & Pres. of the label & -0.083 & 0.062 & -1.327 & 0.185 & \\
\hline & Credibility of the sust. message & 0.245 & 0.032 & 7.580 & $<0.001$ & \\
\hline
\end{tabular}

* Sustainability.

These results lead us to affirm that the perceived credibility of the sustainability message acts as a mediator in the context of the relationships between the self-declared claims and the dependent variables, thus helping to explain the relationships between these variables. To identify the type of mediation, we can compare the significance of the relationships without considering $\mathrm{M}$ and "controlling for $\mathrm{M}^{\prime \prime}$.

With reference to the relationships between our independent variables and corporate reliability, we can notice that, without considering $\mathrm{M}$, they were significant, and only the relationship between the presence of the third-party labels and corporate reliability was at the verge of significance $(p=0.090)$. Thus, we can verify the mediating effect only with reference to the relationships between self-declared claims and corporate reliability. The values of $B$ become considerably lower due to the effect of $M$, but in both cases (the relationships with the formal claim and the friendly claim) they are significantly different from 0 , since the $p$-value is still less than 0.05 . This means that the credibility of the sustainability message constitutes a partial mediator of the relationships between self-declared claims and corporate reliability, since only the first three conditions described in Section $2.3[63,64]$ are met.

Moving on to trust in product quality, the relationships with the formal claim and the friendly claim become not-significant due to $\mathrm{M}$; in both cases, the values of $\mathrm{B}$ are not significantly different from $0(p>0.05)$. Thus, the credibility of the sustainability message completely mediates the relationships between the self-declared claims and trust in product quality.

With regards to the presence of the third-party labels, a separate discussion must be made. In fact, without considering $M$, the relationship with the dependent variable was not-significant, while, controlling for $\mathrm{M}$, it becomes significant. In this case, a significant indirect relationship exists between third-party labels and trust, that is, there exists a relationship due to the mediator.

Additionally, with reference to the relationships between self-declared claims and behavioral intentions we can observe that, due to the presence of $M$, they become non-significant, because $B$ is not significantly different from $0(p>0.05)$. In light of this, we can affirm that the credibility of the sustainability message constitutes a "complete" mediator of the relationships between self-declared claims and behavioral intentions. Moreover, a significant indirect relationship exists between third-party labels and behavioral intentions, as illustrated with regards to trust in product quality.

Finally, we analyze the results with regards to the willingness to pay. The relationship with the formal claim, previously significant, becomes not-significant. Instead, the relationship between the friendly claim and the willingness to pay, which was significant without considering $M$, is now on the verge of significance $(p=0.071)$. In both cases, the value of the coefficient regression is not significantly different from 0 (with $p>0.05$ ), thus, identifying complete mediations. The relationship between third-party labels and the willingness to pay remains not-significant even in the presence of the mediator. 
On the basis of these results, hypothesis 4 finds partial support-the perceived credibility of the sustainability message acts as a mediator of the relationships between self-declared claim (especially if it is expressed through a formal tone of voice) and consumer responses, while it does not constitute a mediator of the relationships between third-party labels and consumer perceptions, intentions, and willingness to pay. In other words, on the basis of these results, we can affirm that this variable can be useful in explaining only the relationships between self-declared claims and consumer responses.

\section{Discussion and Conclusions}

\subsection{Discussion}

In this paper an experimental study aimed at detecting causal relationships between sustainable labeling (in the form of third-party labels or self-declared claim) and consumers' perceptions (concerning product quality and company's reliability), purchase intention, and willingness to pay, is presented. Furthermore, the role of another variable (the credibility of the sustainability message), considered to be a hypothetical mediator between the examined relationships, is taken into consideration.

Surprisingly, there are no significant relationships between TPLs and the dependent variables. Third-party labels, "alone", do not make the difference. This finding is inconsistent with the results of various previous studies $[38,41,67]$, which argued that certifications delivered by independent third parties were perceived more favorably by consumers (than self-declarations) but reinforces Dekhili and Achabou [34] conclusions, who found that self-declarations influenced consumer preferences in virtually the same way as independent certifications. Moreover, this is in line with the Ertz et al. study [47], which showed that third-party environmental labeling alone did not significantly alter consumers' evaluations of product quality, credibility, and their willingness to pay.

The reasons why the TPLs, although correctly associated with an external certification by the participants in this study, did not impact, as expected, on their perceptions (i.e., trust in product quality and corporate reliability), intentions, and willingness to pay might be better understood in light of some considerations:

1. Information implied by socio-environmental labels must be noticed [38,45], understood in their basic meaning/purpose, and perceived as credible by the customers. In other words, labels can act as effective signals only to the degree that consumers deem them both useful and credible [68].

2. With reference to food products and especially to a special, "self-indulgent treat" product, like chocolate, other aspects (like the taste, price, brand, etc.) could maintain greater importance than socio-environmental attributes in the habitual purchasing path, followed by the consumer [49].

Previous studies pointed out that labeling schemes were effective only if consumers were informed and aware of their meaning, characteristics, requirements, etc. [69-74]. If the labels are unknown or their meaning unclear, even the most sustainability-oriented consumer cannot use them [71].

In this study, it was evident that even though participants were able to visually recognize the TPL's (as the manipulation check confirmed), respondents showed an overall limited understanding of the labels' purposes. This problem was not specifically related to the respondents' selection adopted in the study, since it appeared in several other studies that showed that the overall knowledge on labeling and socio-environmental labels in general terms is limited [70,71], and varies across countries [75,76]. A European on-line survey of around 4000 consumers in six countries (UK, France, Germany, Spain, Sweden, and Poland) found that people had a limited understanding of the actual meaning of four selected labels (Fair Trade, Rainforest Alliance, Carbon Footprint, and Animal Welfare) and highlighted the existence of considerable differences across the six countries considered [77]. Similar cross-country differences also emerged in other studies $[71,72,76]$, suggesting that the diversified level of prominence 
of sustainability issues on the public agenda can influence the salience of the concept, in the mind of consumers.

In addition to the national setting, other determinants of understanding of sustainability labels were found to be related to age (with younger respondents showing a higher level of understanding than the overall population) and levels of education, with higher levels of understanding for higher levels of education [71].

In other words, the goal of sustainability labels is to reduce information asymmetry between the producer and the consumer regarding the socio-environmental attributes of a product, but this goal can be reached only if the consumer is motivated and sustains a cognitive effort in information processing and detailed decision-making. Highly educated individuals are the ones who are more likely to own the cognitive resources needed to sustain a high effort adoption process, which is required in relation to certification schemes $[73,78]$, to understand the meaning of labels and to process it for the purpose of the purchase decision. However, when consumers fear the risk of being cheated [21,22] but also when they perceive a sensation of "information overload", engendered by the increasing number of labeling schemes, substantial confusion might be generated in their mind [79,80], reducing their ability to decide or producing even negative reactions toward labels [72-74].

Additional cognitive effort on the part of the consumer is therefore needed in these occasions, as well as when the label is poorly communicated and is not capable of being sufficiently self-explanatory. In this context, previous studies outlined [71] that some labels communicated themselves fairly well even to respondents who had not seen them before, while others were not that able. Creating a self-explanatory label is a challenge, made even more complex by the limited space available on the packaging, which makes it difficult to communicate its meaning while grabbing consumers' attention. The results from this study (Section 3.2) confirm what already emerged in past literature [49]—information related to the socio-environmental commitment of the producer is not the first element that the consumer considers when he has to buy a food product, especially a self-indulgent one like chocolate. Nevertheless, sustainability information becomes meaningful when other purchasing criteria (such as price and taste) are satisfied [79], because in this case a private benefit, such as the pleasure of eating chocolate, is jointly obtained with a public one, like social-environmental protection [74]. At these conditions, sustainability schemes act as a heuristic tool, provided that they are noticed and easily interpreted. From this point of view, we can understand the reasons why, in the present study, a self-declared claim, expressed in a textual, well-focused, and unambiguous way, proved to be more effective than third-party logos; being capable of transferring, with a minimum decoding effort, the intended message to the consumer, the textual message was more easily incorporated into consumers' chains of comprehension, action, and response.

In fact, multiple regression revealed that self-declared claims, especially in the case of a formal tone of voice, played a particularly relevant role in influencing the dependent variables. Contrary to the expectations and denying the hypothesis $\mathrm{H} 2 \mathrm{~b}$, when the self-declared claim was delivered through a more friendly copy, it turned out to be less effective than when it was conveyed with a more formal tone of voice.

The most incisive role of the formal claim can be explained first by considering that when confronted with socio-environmental issues, respondents were more sensitive to formal messages which appeared to be more reassuring (than a playful message winking at the consumer) and helped them to banish the specter of greenwashing [21,22], reducing the sensation of information overload $[79,80]$. Participants in this study had an even greater need for reassurance because they were exposed to the product packaging of an unknown (fictitious) brand, so they could not base their assessments on the previous trust or corporate reputation.

These are probably the main reasons why the friendly claim "alone" turned out to be less effective than the formal one in relation to all dependent variables, with the sole exception of the willingness to pay. This specific finding might be partially explained by considering that the consumer had little to lose, in an experimental condition, by rewarding the corporation and evaluating it positively for 
coming up with a "nice message" about sustainability. Consumers appreciation for an emotional copy claim (perceived as more "likable" or "enjoyable") might have induced some of the interviewees to respond on the wave of the emotional impulse (exactly what the claim wanted to evoke) by declaring their willingness to pay a higher price. However, when it comes to evaluating the intention to purchase, the confidence in the quality of the product or the reliability of the company, the emotional wave tends to subside and the friendly claim turns out to be less effective than the formal one. In other words, a more emotional message can receive a premium price on the basis of an "affective" trust, which differs from the cognitive trust and does not necessarily convert into other consumer's responses, like declared intention to buy or to activate word-of-mouth [81].

Concerning the willingness to pay, the results obtained through multiple regression allow to almost completely confirm H3-the declared willingness to pay was maximum (€1.69) when the TPLs and self-declared claims were simultaneously displayed on the product packaging, and minimum (€1.24) when only the TPLs, without a self-declared claim (condition 4) appeared on the pack. More in detail, the highest willingness to pay (€1.69) was declared when the TPLs were combined with an informal self-declared one. When the TPLs were combined with a formal self-declared claim (condition 5), the consumer declared to be willing to pay a maximum price of $€ 1.48$, which was quite similar to the one declared in relation to a product packaging, showing only an informal claim without third-party labels (condition 3).

We can thus affirm that third-party labels and self-declared claims are both necessary-the former ones act as a guarantor but are not always self-explanatory, and can be insufficient when used "alone"; the latter ones are better at drawing the consumer's attention to the sustainable benefits related to the product, conveying additional information that justifies the higher willingness to pay (that respondents declared when firm-level labels were combined with TPLs).

Finally, with respect to the hypothesized mediating role of the perceived credibility of the sustainability message (H4), our results highlight the mediating role of the perceived credibility with reference to the relationships between self-declared claims and customer perceptions/intentions and WTP. This confirms that the perceived credibility of the sustainability message is largely responsible for the significance of the relationships. This does not happen in the case of the third-party labels, in relation to which the problems arising from the limited levels of familiarity/understanding and credibility are already highlighted above.

\subsection{Theoretical and Practical Implications}

The present study examines the propensity of consumers to consider self-declared claims, in comparison with TPLs, in the case of an unknown brand. Moreover, it investigates multiple levels and forms of sustainability information, as well as multiple kinds of dependent variables of different nature (consumer's perceptions, purchase intention, and willingness to pay).

Our findings question the conclusions that affirm the superiority of independent certifications and the untrustworthiness of a company's self-declared claims $[38,41,67]$, and are in line with studies highlighting that sustainability third-party labels "alone" do not currently play a major role in consumers' food choices [71,72,82]. Our results confirm the efficacy of internal socio-environmental claims, not only in the case of a well-known brand—as outlined in the study of Dekhili and Achabou [34] — but also with reference to an unknown one. A short, focused, clearly written sentence-stating the company's sustainability engagement-can influence consumers' perceptions and intentions more than TPLs, even when corporate reputation and brand image do not support consumer's choice, playing their role of "cognitive shortcuts" and enabling the consumer to rapidly identify trustworthy companies, on the basis of previous knowledge.

Our experimental study provides some insights into the effects of the tone of voice that should be adopted to convey the self-declared claim, suggesting that a "formal" tone of voice is preferable, with respect to a more friendly one. A formal claim is more effective in influencing young consumers' trust and their perception of corporate reliability, even because it has a stronger impact on the perceived 
credibility of the sustainability message, which as was observed, acted as a mediator between the self-declared claim and the dependent variables. For these reasons, especially if they cannot count on strong brand equity, companies should shun the temptation of acting on the emotional lever when defining the copy to articulate their sustainability claim, since young consumers seem to follow more the "cognitive" route, than the "affective" one, in addressing their evaluations/choices; the latter, more intuitive, only tended to affect the declared willingness to pay, without impacting the perceived credibility of the message as well as consumer trust, in a significant manner.

A further practical implication that does not directly concern individual companies is related to the need to implement actions aimed at improving consumer knowledge of the TPLs. Only a clearer understanding of the labels and of their meaning could increase their effectiveness. In this context, sustainability labels regularly face challenges in terms of the limited space available on the packaging that does not contribute to increasing their clarity. This issue could be tackled by the use of innovative IT solutions (e.g., through the use of barcode scanners, QR codes, etc.) to provide further information to consumers. Furthermore, when socio-environmental labels are not self-explanatory for consumers, they could be complemented by other tools (e.g., website and social media campaigns, leaflets, actions at the point of sale, etc.).

\subsection{Conclusions}

Consumer awareness of sustainability certification schemes increased in the past two decades, though still showing significant cross-country differences. Despite this, sustainability third-party labels currently do not play a major role in consumers' food choices and still register a limited level of familiarity/understanding among young consumers, even if our study revealed significant differences among four different labels. This does not mean that companies should reduce their socio-environmental commitment or stop investing in certification schemes, which moreover are frequently used by other categories of stakeholders, such as NGOs, to assess their ethical and environmental performances.

Our results suggest that when a company decides to invest in a labeling procedure, it should seek to jointly elaborate self-declared claims in order to better convey important information that is typically not transmitted by the TPL alone. The latter can certainly act as a guarantor toward more informed consumers and other company's stakeholder but might be insufficient in providing a clear and effective communication, capable of representing the sustainability characteristics of the product at the best, so that consumers can easily perceive the relative benefit. It is therefore up to the organization to convey additional and more concrete information in order to maximize the benefits that can be derived from its investments. However, if producers place their socio-environmental declarations alongside third-party labels, further proliferation of environmental declarations is engendered, with the risk of aggravating the aforementioned problem of information overload. In this regard, since the use of the sustainability self-declared claims is still loosely (or not at all) regulated in many countries and too many times marketers still incur in one or more "sins" of greenwashing, it could be opportune for policymakers to provide rules/guidelines producers should respect when stating their socio-environmental commitment, through on-pack labeling. Different countries created legislation regarding nutritional labels, it could be useful to also intervene with reference to sustainable information. Similar interventions should be adopted with the aim of guaranteeing to all parties and consumers in particular, their right to truthful, useful, and substantiated sustainable on-pack information.

\subsection{Limitations and Further Research}

As with all empirical work, some limitations, offering guidance for further research, should be taken into account.

First, this research is referred to one specific product context, the food sector and future experiments should be conducted within other sectors to check whether the results carry over.

A second limitation is related to the artificial environment, an online "laboratory", where the experiment was conducted. Though mitigated by presenting high-quality visual stimuli to participants, 
inevitably their choice situation obviously missed a variegated range of cues present in a natural setting. The fictitious product brand used in the study could represent another missing cue, as mentioned before. Although the research team deliberately chose to refer to an imaginary brand (to avoid possible bias due to respondents' prior knowledge and attitudes towards a specific brand), brand knowledge can undeniably make a strong difference in determining consumer's response to the marketing stimuli. In this context, the perceived credibility of the sustainable message might be influenced through consumers' moral affective evaluation of the product/brand, which in turn, could be related to corporate reputation - what consumers already know and perceive about a brand, how (and if) they feel engaged in their relationship with the company, are all aspects that can strongly influence their perceptions/intentions toward the brand.

We already mentioned above the reason for choosing the sample used in the study. Although this might be viewed as a sample of convenience, younger people (millennials and post-millennials) are consumers that are more oriented toward sustainability, have a huge collective spending power, and are an increasingly important consumer group. Understanding their responses to sustainability labels is, therefore, an essential undertaking, even though these findings might not be generalizable to the population as a whole, or other countries.

Finally, both the sustainability labels included in the study, the external and the self-declared one, were respectively presented in only two variants. In addition, TPLs were presented in a graphic format (a logo), while self-declared claims were presented in a textual format. Future research could therefore explore a more variegated manipulation, considering other labels (or their different combinations) and further variations of the internal claim tone of voice, beside the two modes ("formal" and "friendly") considered here. Further studies could also consider comparing the effectiveness of "textual" self-declared claims versus "only graphic" ones.

Author Contributions: Conceptualization and Methodology: C.R.; Investigation: C.R. and F.R.; Formal Analysis: F.R.; Visualization and Writing: C.R. and F.R.; Supervision: C.R. All authors have read and agreed to the published version of the manuscript.

Funding: This work received no funding.

Conflicts of Interest: The authors declare no conflict of interest.

\section{Appendix A}

Table A1. Questionnaire Structure.

\begin{tabular}{|c|c|}
\hline \multirow{4}{*}{ 1. Buying behavior } & $\begin{array}{l}\text { How often do you read the following information on the product } \\
\text { packaging? }(1=\text { never; } 5=\text { always })\end{array}$ \\
\hline & $\begin{array}{ll}- & \text { Price } \\
- & \text { Calories } \\
- & \text { Expiration date } \\
- & \text { List of ingredients } \\
- & \text { Country of origin of raw materials } \\
- & \text { Manufacturing plant } \\
- & \text { Brand of the manufacturer }\end{array}$ \\
\hline & $\begin{array}{l}\text { When you have to buy a chocolate bar of chocolate, how important do } \\
\text { you think each of the following element is for the purpose of your } \\
\text { choice? ( } 1=\text { not at all important; } 5=\text { extremely important })\end{array}$ \\
\hline & $\begin{array}{ll}- & \text { Product Taste } \\
- & \text { Brand notoriety } \\
- & \text { Socio-ethical commitment of the producer } \\
- & \text { Environmental commitment of the producer } \\
- & \text { Price } \\
- & \text { Country of origin of raw materials } \\
- & \text { Country of Production } \\
- & \text { Expiration date } \\
- & \text { Nutritional information }\end{array}$ \\
\hline
\end{tabular}


Table A1. Cont.

Please, look carefully at the image shown below, assuming this tablet is both of your favorite flavor and the format you usually buy.

Next, indicates how much you agree with each of the following

statements ( $1=$ in complete disagreement; $5=$ completely agree).

- $\quad$ [Organization] is a firm I can trust

- The [Organization] is a firm that cares about its customers

- The environmental commitment announced on the package appears to be trustworthy in my eyes

- The company is believable when it communicates its efforts to reduce its impact on the environment

- $\quad$ The environmental information included in the packaging seems

2. Experiment truthful to me

- $\quad$ To produce this chocolate bar the company used sustainably produced materials

- This product provides me with an impression of being of good quality

- $\quad$ I trust the quality of this product

- If I had to buy a chocolate bar, there is a strong likelihood that I would buy the product here represented

- I would recommend this product to my friends

- Information on the company's socio-environmental efforts is certified by third parties

The average price of a chocolate bar is $€ 1.10$. To buy the bar seen in the picture, how much would you be willing to pay?

Please, look carefully at this symbol (for each of the four TPL's

considered). Could you tell us what it indicates? (Yes/No) What purpose do you most associate with the symbol just presented? (please select one answer)

- $\quad$ Ensuring lower prices for consumers

3. Familiarity with different sustainability labels

- $\quad$ Protecting organic products

- Preserving biodiversity and ensuring sustainable living conditions

- Ensuring sustainability and transparency in the coffee and cocoa supply chain

- Ensuring decent living conditions and fair contractual terms for producers and workers

- I don't know

Table A2. Reading of the information on the package (frequency: $1=$ never; $5=$ always).

\begin{tabular}{cc}
\hline Variables & Mean \\
\hline Price & 4.42 \\
\hline Expiration date & 4.10 \\
\hline Calories & 2.73 \\
\hline List of ingredients & 3.04 \\
\hline Country of origin of raw materials & 2.72 \\
\hline Manufacturing plant & 2.71 \\
\hline Brand of the manufacturer & 3.96 \\
\hline
\end{tabular}


Table A3. Aspects considered when buying chocolate ( $1=$ not at all important; $5=$ extremely important).

\begin{tabular}{cc}
\hline Variables & Mean \\
\hline Product taste & 4.75 \\
\hline Brand notoriety & 3.25 \\
\hline Socio-ethical commitment of the producer & 3.01 \\
\hline Environmental commitment of the producer & 3.10 \\
\hline Price & 4.13 \\
\hline Country of origin of raw materials & 2.96 \\
\hline Country of Production & 3.04 \\
\hline Expiration date & 3.99 \\
\hline Nutritional information & 3.21 \\
\hline
\end{tabular}

Table A4. Customer perceptions and intentions $(1=$ completely disagree; $5=$ completely agree $)$.

\begin{tabular}{|c|c|c|c|c|c|c|}
\hline \multirow[t]{2}{*}{ Variables } & \multicolumn{6}{|c|}{ Mean } \\
\hline & Cond. 1 & Cond. 2 & Cond. 3 & Cond. 4 & Cond. 5 & Cond. 6 \\
\hline Trust in the Company & 3.04 & 3.73 & 3.37 & 3.15 & 3.81 & 3.65 \\
\hline Attention to consumers & 2.67 & 3.52 & 3.41 & 2.95 & 3.77 & 3.48 \\
\hline Purchase intention & 2.80 & 3.38 & 3.12 & 2.67 & 3.49 & 3.29 \\
\hline Use of sustainably produced materials & 3.11 & 3.73 & 3.55 & 3.36 & 4.13 & 3.79 \\
\hline Perceived quality & 3.22 & 3.62 & 3.59 & 3.05 & 3.85 & 3.63 \\
\hline Trust in the quality of the product & 2.94 & 3.29 & 3.33 & 2.95 & 3.57 & 3.40 \\
\hline Intention of positive word of mouth & 2.80 & 3.25 & 2.88 & 2.69 & 3.21 & 3.29 \\
\hline $\begin{array}{l}\text { Trustworthiness of the } \\
\text { environmental commitment }\end{array}$ & 2.63 & 3.79 & 3.41 & 3.16 & 3.79 & 3.48 \\
\hline $\begin{array}{l}\text { Credibility of the communication } \\
\text { relating to the env. commitment }\end{array}$ & 2.76 & 3.63 & 3.27 & 3.18 & 3.72 & 3.54 \\
\hline $\begin{array}{l}\text { Truthfulness of environmental } \\
\text { information on the package }\end{array}$ & 2.50 & 3.52 & 3.22 & 3.24 & 3.89 & 3.48 \\
\hline $\begin{array}{l}\text { Adequacy of communicated } \\
\text { environmental efforts }\end{array}$ & 2.33 & 3.12 & 2.73 & 2.75 & 3.26 & 2.90 \\
\hline Third-party certification & 2.30 & 2.46 & 2.16 & 2.98 & 3.02 & 2.96 \\
\hline
\end{tabular}

Table A5. The willingness to pay.

\begin{tabular}{ccccccc}
\hline Variable & \multicolumn{6}{c}{ Mean } \\
\hline & Cond. 1 & Cond. 2 & Cond. 3 & Cond. 4 & Cond. 5 & Cond. 6 \\
\hline Price & 1.42 & 1.52 & 1.48 & 1.24 & 1.48 & 1.69 \\
\hline
\end{tabular}

Table A6. Declared number of familiar labels for each condition.

\begin{tabular}{ccccccc}
\hline Number of Labels & Condition 1 & Condition 2 & Condition 3 & Condition 4 & Condition 5 & Condition 6 \\
\hline 0 & $14.82 \%$ & $19.23 \%$ & $20.41 \%$ & $12.73 \%$ & $22.64 \%$ & $11.54 \%$ \\
\hline 1 & $33.33 \%$ & $32.69 \%$ & $28.57 \%$ & $36.36 \%$ & $32.08 \%$ & $40.38 \%$ \\
\hline 2 & $35.19 \%$ & $34.62 \%$ & $30.61 \%$ & $27.27 \%$ & $28.30 \%$ & $26.92 \%$ \\
\hline 3 & $12.96 \%$ & $7.69 \%$ & $14.29 \%$ & $18.18 \%$ & $9.43 \%$ & $15.39 \%$ \\
\hline 4 & $3.70 \%$ & $5.77 \%$ & $6.12 \%$ & $5.46 \%$ & $7.55 \%$ & $5.77 \%$ \\
\hline Total & $100.00 \%$ & $100.00 \%$ & $100.00 \%$ & $100.00 \%$ & $100,00 \%$ & $100.00 \%$ \\
\hline
\end{tabular}


Table A7. Participants divided by gender, generation, education level, and family size.

\begin{tabular}{llc}
\hline \multicolumn{1}{c}{ Variables } & \multicolumn{1}{c}{ Modalities } & $\%$ \\
\hline Gender & Male & $36.51 \%$ \\
& Female & $63.49 \%$ \\
\hline Generation & Millennials & $52.38 \%$ \\
& Post-millennials & $47.62 \%$ \\
\hline Education level & High school graduate & $50.48 \%$ \\
& University undergraduate & $36.82 \%$ \\
& University graduate & $12.70 \%$ \\
\hline Family size & 1 & $2.22 \%$ \\
& 2 & $7.30 \%$ \\
& 3 & $17.46 \%$ \\
& 4 & $51.43 \%$ \\
& 5 & $14.92 \%$ \\
& 6 & $4.76 \%$ \\
& 7 & $1.91 \%$ \\
\hline
\end{tabular}

\section{References}

1. Chekima, B.; Igau, A.; Wafa, S.A.W.S.K.; Chekima, K. Narrowing the gap: Factors driving organic food consumption. J. Clean. Prod. 2017, 166, 1438-1447. [CrossRef]

2. Carrington, M.J.; Zwick, D.; Neville, B. The ideology of the ethical consumption gap. Mark. Theory. 2016, 1, 21-38. [CrossRef]

3. Clark, G. Evolution of the global sustainable consumption and production policy and the united nations environment programmes (UNEP) supporting activities. J. Clean. Prod. 2007, 15, 492-498. [CrossRef]

4. Yamoah, F.A.; Acquaye, A. Unravelling the attitude-behaviour gap paradox for sustainable food consumption: Insight from the UK Apple market. J. Clean. Prod. 2019, 217, 172-184. [CrossRef]

5. Boulstridge, E.; Carrigan, M. Do consumers really care about corporate responsibility? Highlighting the attitude-behaviour gap. J. Commun. Manag. 2000, 4, 355-368. [CrossRef]

6. Carrington, M.J.; Neville, B.A.; Whitwell, G.J. Why ethical consumers don't walk their talk: Towards a framework for understanding the gap between the ethical purchase intentions and actual buying behaviour of ethically minded consumers. J. Bus. Ethics 2010, 97, 139-158. [CrossRef]

7. Luchs, M.G.; Naylor, R.W.; Irwin, J.R.; Raghunathan, R. The sustainability liability: Potential negative effects of ethicality on product preference. J. Mark. 2010, 74, 18-31. [CrossRef]

8. Newholm, T.; Shaw, D. Studying the ethical consumer: A review of research. J. Consum. Beh. 2007, 6, 253-270. [CrossRef]

9. Auger, P.; Devinney, T.M. Do what consumers say matter? The misalignment of preferences with unconstrained ethical intentions. J. Bus. Ethics 2007, 76, 361-383. [CrossRef]

10. Young, W.; Hwang, K.; McDonald, S.; Oates, C.J. Sustainable consumption: Green consumer behaviour when purchasing products. Sustain. Dev. 2010, 18, 20-31. [CrossRef]

11. Terlau, W.; Hirsch, D. Sustainable consumption and the attitude-behaviour-gap phenomenon-causes and measurements towards a sustainable development. Int. J. Food Syst. Dyn. 2015, 6, 159-174. [CrossRef]

12. Jacobs, K.; Petersen, L.; Hörisch, J.; Battenfeld, D. Green thinking but thoughtless buying? An empirical extension of the value-attitude-behaviour hierarchy in sustainable clothing. J. Clean. Prod. 2018, 203, 1155-1169. [CrossRef]

13. Prothero, A.; Dobscha, S.; Freund, J.; Kilbourne, W.E.; Luchs, M.G.; Ozanne, L.K.; Thøgersen, J. Sustainable consumption: Opportunities for consumer research and public policy. J. Publ. Policy Mark. 2011, 30, 31-38. [CrossRef]

14. Johnstone, M.; Tan, L.P. Exploring the gap between consumers' green rhetoric and purchasing behaviour. J. Bus. Ethics 2015, 132, 311-328. [CrossRef]

15. Nielsen. What's Sustainability Got to Do with It? Linking Sustainability Claims to Sales. 2018. Available online: https:/www.nielsen.com/us/en/insights/report/2018/whats-sustainability-got-to-do-withit/ (accessed on 3 October 2020). 
16. Mohr, L.A.; Webb, D.J.; Harris, K.E. Do consumers expect companies to be socially responsible? The impact of corporate social responsibility on buying behavior. J. Consum. Aff. 2001, 35, 45-72. [CrossRef]

17. Morsing, M.; Schultz, M. Corporate social responsibility communication: Stakeholder information, response and involvement strategies. Bus. Ethics Eur. Rev. 2006, 15, 323-338. [CrossRef]

18. Xiaoli, N.; Kwangjun, H. Consumer responses to corporate social responsibility (CSR) initiatives. J. Advert. 2007, 36, 63-74.

19. Bublitz, M.G.; Peracchio, L.A.; Block, L.G. Why did I eat that? Perspectives on food decision making and dietary restraint. J. Consum. Psychol. 2010, 20, 239-258. [CrossRef]

20. Barreau, B.; Vielliard, F. L'affichage environnemental des produits de consommation courante: Les conditions de la réussite. Ann. Mines Responsab. Environ. 2014, 73, 19-22. [CrossRef]

21. Nyilasy, G.; Gangadharbatla, H.; Paladino, A. Perceived greenwashing: The interactive effects of green advertising and corporate environmental performance on consumer reactions. J. Bus. Ethics 2014, 125, 693-707. [CrossRef]

22. Parguel, B.; Benoît-Moreau, F.; Larceneux, F. How sustainability ratings might deter 'greenwashing': A closer look at ethical corporate communication. J. Bus. Ethics 2011, 102, 15-28. [CrossRef]

23. Gruère, G. A Characterisation of Environmental Labelling and Information Schemes (ELIS); OECD Environment Working Paper; OECD iLibrary: Paris, France, 2013; Volume 62. [CrossRef]

24. Marder, N.; Dodd, C.E. The responsible consumer's view of green labels: Lessons from two greenwashing cases. Glob. Cosm. Ind. 2012, 180, 48-50.

25. Benoît-Moreau, F.; Parguel, B.; Larceneux, F. Comment prévenir le greenwashing? L'influence des éléments d'exécution publicitaire. Etats Généraux du Manag. 2008. Available online: https://halshs.archives-ouvertes. fr/halshs-00336129/document (accessed on 3 October 2020).

26. Benoît-Moreau, F.; Larceneux, F.; Parguel, B. Mieux vaut bien faire et le faire dire: Le rôle des notations environnementales dans la régulation greenwashing. Etats Généraux Manag. 2010. Available online: https://halshs.archives-ouvertes.fr/halshs-00636236/document (accessed on 3 October 2020).

27. Cui, Y.; Trent, E.; Sullivan, P.; Matiru, G. Cause-related marketing: How generation y responds. Int. J. Retail. Distrib. Manag. 2003, 31, 310-320. [CrossRef]

28. Kanchanapibul, M.; Lacka, E.; Wang, X.; Chan, H.K. An empirical investigation of green purchase behaviour among the young generation. J. Clean. Prod. 2014, 66, 528-536. [CrossRef]

29. Lee, K. Opportunities for green marketing: Young consumers. Mark. Intell. Plan. 2008, 26, 573-586. [CrossRef]

30. Grønhøj, A.; Thøgersen, J. Like father, like son? Intergenerational transmission of values, attitudes, and behaviours in the environmental domain. J. Environ. Psychol. 2009, 29, 414-421. [CrossRef]

31. Naderi, I.; Van Steenburg, E. Me first, then the environment: Young millennials as green consumers. Young Consum. 2018, 19, 280-295. [CrossRef]

32. Salvia, R.; Quaranta, G. Multi-Actor Platform as a tool to enhance networking of sustainable socio-ecological food systems. Economia Agro-alimentare 2019, 2, 405-427. [CrossRef]

33. Chen, Y.; Chang, C. Enhance green purchase intentions: The roles of green perceived value, green perceived risk and green trust. Manag. Decis. 2012, 50, 502-520. [CrossRef]

34. Dekhili, S.; Achabou, M.A. Eco-labelling brand strategy. Independent certification versus self-declaration. Eur. Bus. Rev. 2014, 26, 205-329. [CrossRef]

35. Allison, C.; Carter, A. Study on Different Types of Environmental Labelling (ISO Type II and III Labels): Proposal for an Environmental Labelling Strategy; Report prepared by ERM Consultants for DG Environment: Brussels, Belgium, 2000.

36. Gordon, R.; Carrigan, M.; Hastings, G. A framework for sustainable marketing. Mark. Theo. 2011, 11, $143-163$. [CrossRef]

37. Moisander, J. Motivational complexity of green consumerism. Int. J. Consum. Stud. 2007, 31, 404-409. [CrossRef]

38. Thøgersen, J. Psychological determinants of paying attention to eco-labels in purchase decisions: Model development and multinational validation. J. Consum. Policy 2000, 23, 285-313. [CrossRef]

39. Larceneux, F. Segmentation des signes de qualité: Labels expérientiels et labels techniques. Décisions Mark. 2003, 29, 35-46. [CrossRef]

40. Laufer, W.S. Social accountability and corporate greenwashing. J. Bus. Ethics 2003, 43, 253-261. [CrossRef]

41. Horne, R.E. Limits to labels: The role of eco-labels in the assessment of product sustainability and routes to sustainable consumption. Int. J. Consum. Stud. 2009, 33, 175-182. [CrossRef] 
42. Topolansky Barbe, F.G.; Gonzalez-Triay, M.M.; Hensel, A. Eco-labels in Germany. J. Cust. Behav. 2013, 12, 341-359. [CrossRef]

43. Mason, C.F. An economic model of ecolabeling. Environ. Model. Assess. 2006, 11, 131-143. [CrossRef]

44. Larceneux, F.; Benoit-Moreau, F.; Renaudin, V. Why might organic labels fail to influence consumer choices? Marginal labelling and brand equity effects. J. Consum. Policy 2012, 35, 85-104. [CrossRef]

45. Thøgersen, J. Promoting green consumer behavior with eco-labels. In New Tools for Environmental Protection: Education, Information, and Voluntary Measures; Dietz, T., Stern, P.C., Eds.; National Academy Press: Washington, DC, USA, 2002; pp. 83-104.

46. Gosselt, J.F.; van Rompay, T.; Haske, L. Won't get fooled again: The effects of internal and external CSR ECO-labeling. J. Bus. Ethics 2019, 155, 413-424. [CrossRef]

47. Ertz, M.; François, J.; Durif, F. How consumers react to environmental information: An experimental study. J. Int. Consum. Mark. 2017, 29, 162-178. [CrossRef]

48. Tagbata, D.; Sirieix, L. Measuring consumer's willingness to pay for organic and fairtrade products. Int. J. Consum. Stud. 2008, 32, 479-490. [CrossRef]

49. Rousseau, S. The role of organic and fairtrade labels when choosing chocolate. Food Qual. Prefer. 2015, 44, 92-100. [CrossRef]

50. Atkinson, L.; Rosenthal, S. Signaling the green sell: The influence of eco-label source, argument specificity, and product involvement on consumer trust. J. Advert. 2014, 43, 33-45. [CrossRef]

51. Keeling, K.; McGoldrick, P.; Beatty, S. Avatars as salespeople: Communication style, trust, and intentions. J. Bus. Res. 2010, 63, 793-800. [CrossRef]

52. Shimp, T.A.; Andrews, J.C. Advertising, Promotion and Supplemental Aspects of Integrated Marketing Communications; Thomson South-Western: Mason, OH, USA, 2013; pp. 1-752.

53. Geuens, M.; De Pelsmacker, P.; Faseur, T. Emotional advertising: Revisiting the role of product category. J. Bus. Res. 2011, 64, 418-426. [CrossRef]

54. KPMG Cocoa Certification: Study on the Costs, Advantages and Disadvantages of Cocoa Certification. Commissioned by The International Cocoa Organization (ICCO). 2012. Available online: https://www.icco.org/about-us/international-cocoa-agreements/cat_view/30-related-documents/37-fairtrade-organic-cocoa.html (accessed on 3 October 2020).

55. Cerri, J.; Thøgersen, J.; Testa, F. Social desirability and sustainable food research: A systematic literature review. Food Qual. Prefer. 2019, 71, 136-140. [CrossRef]

56. ISO Central Secretariat. Environmental Labels and Declarations. How ISO standards help. 2012. Available online: http://www.iso.org/iso/environmental-labelling.pdf. (accessed on 3 October 2020).

57. Bradu, C.; Orquin, J.L.; Thøgersen, J. The mediated influence of a traceability label on consumer's willingness to buy the labelled product. J. Bus. Ethics 2014, 124, 283-295. [CrossRef]

58. Mohr, L.A.; Eroğlu, D.; Scholder Ellen, P. The development and testing of a measure of skepticism toward environmental claims in marketers' communications. J. Consum. Aff. 1998, 32, 30-55. [CrossRef]

59. Becker-Olsen, K.L.; Cudmore, B.A.; Hill, R.P. The impact of perceived corporate social responsibility on consumer behavior. J. Bus. Res. 2006, 59, 46-53. [CrossRef]

60. Azhar, A.K.M.; Elliott, R., Jr. On the measurement of product quality in intra-industry trade. Rev. World Econ. 2006, 142, 476-495. [CrossRef]

61. Dodds, W.B.; Monroe, K.B.; Grewal, D. Effects of price, brand, and store information on buyers' product evaluations. J. Mark. Res. 1991, 28, 307-319. [CrossRef]

62. Cameron, T.A.; James, M.D. Estimating willingness to pay from survey data: An alternative pre-test-market evaluation procedure. J. Mark. Res. 1987, 24, 389-395. [CrossRef]

63. Baron, R.M.; Kenny, D.A. The moderator-mediator variable distinction in social psychological research: Conceptual, strategic, and statistical considerations. J. Pers. Soc. Psychol. 1986, 51, 1173-1182. [CrossRef]

64. Kenny, D.A.; Kashy, D.A.; Bolger, N. Data analysis in social psychology. In The Handbook of Social Psychology, 4th ed.; Gilbert, D.T., Fiske, S.T., Lindzey, G., Eds.; McGraw-Hill: New York, NY, USA, 1998; Volume 1, pp. 233-265.

65. Shrout, P.E.; Bolger, N. Mediation in experimental and nonexperimental studies: New procedures and recommendations. Psychol. Methods 2002, 7, 422-445. [CrossRef]

66. Zhao, X.; Lynch, J.G., Jr.; Chen, Q. Reconsidering Baron and Kenny: Myths and truths about mediation analysis. J. Consum. Res. 2010, 37, 197-206. [CrossRef] 
67. Leire, C.; Thidell, Å. Product-related environmental information to guide consumer purchases-a review and analysis of research on perceptions, understanding and use among Nordic consumers. J. Clean. Prod. 2005, 13, 1061-1070. [CrossRef]

68. Boulding, W.; Kirmani, A. A consumer-side experimental examination of signaling theory: Do consumers perceive warranties as signals of quality? J. Consum. Res. 1993, 20, 111-123. [CrossRef]

69. Testa, F.; Iraldo, F.; Vaccari, A.; Ferrari, E. Why Eco-labels can be Effective Marketing Tools: Evidence from a Study on Italian Consumers. Bus. Strat. Env. 2015, 24, 252-265. [CrossRef]

70. Kaczorowska, J.; Rejman, K.; Halicka, E.; Szczebyło, A.; Górska-Warsewicz, H. Impact of food sustainability labels on the perceived product value and price expectations of urban consumers. Sustainability 2019, 11, 7240. [CrossRef]

71. Grunert, K.G.; Hieke, S.; Wills, J. Sustainability labels on food products: Consumer motivation, understanding and use. Food Policy 2014, 44, 177-189. [CrossRef]

72. Annunziata, A.; Mariani, A.; Vecchio, R. Effectiveness of sustainability labels in guiding food choices: Analysis of visibility and understanding among young adults. Sustain. Prod. Consum. 2019, 17, 108-115. [CrossRef]

73. Thøgersen, J.; Haugaard, P.; Olesen, A. Consumer responses to ecolabels. Eur. J. Mark. 2010, 44, 1787-1810. [CrossRef]

74. Delmas, M.A.; Grant, L.E. Eco-labeling strategies and price-premium: The wine industry puzzle. Bus. Soc. 2014, 53, 6-44. [CrossRef]

75. D'Souza, C.; Taghian, M.; Lamb, P.; Peretiatko, R. Green decisions: Demographics and consumer understanding of environmental labels. Int. J. Consum. Stud. 2007, 31, 371-376. [CrossRef]

76. Alevizou, P.J.; Oates, C.J.; McDonald, S. The well(s) of knowledge: The decoding of sustainability claims in the UK and in Greece. Sustainability 2015, 7, 8729-8747. [CrossRef]

77. EUFIC. Sustainability and Social Awareness Labelling. 2014. Available online: https:/www.eufic.org/it/ collaboration/article/eufic-forum-n-6-sustainability-and-social-awareness-labelling (accessed on 3 October 2020).

78. Peschel, A.O.; Grebitus, C.; Steiner, B.; Veeman, M. How does consumer knowledge affect Environmentally sustainable choices? Evidence from a cross-country latent class analysis of food labels. Appetite 2016, 106, 78-91. [CrossRef]

79. Gadema, Z.; Oglethorpe, D. The use and usefulness of carbon labelling food: A policy perspective from a survey of UK supermarket shoppers. Food Policy 2011, 36, 815-822. [CrossRef]

80. Hartikainen, H.; Katajajuuri, J.-M.; Pulkkinen, H. Finnish consumer perceptions of carbon footprints and carbon labelling of food products. J. Clean. Prod. 2014, 73, 285-293. [CrossRef]

81. Kim, C.; Jeon, H.G.; Lee, C. Discovering the role of emotional and rational appeals and hidden heterogeneity of consumers in advertising copies for sustainable marketing. Sustainability 2020, 12, 5189. [CrossRef]

82. Zander, K.; Padel, S.; Zanoli, R. EU organic logo and its perception by consumers. Br. Food J. 2015, 117, $1506-1526$. [CrossRef]

Publisher's Note: MDPI stays neutral with regard to jurisdictional claims in published maps and institutional affiliations.

(C) 2020 by the authors. Licensee MDPI, Basel, Switzerland. This article is an open access article distributed under the terms and conditions of the Creative Commons Attribution (CC BY) license (http://creativecommons.org/licenses/by/4.0/). 